\title{
At-Taqaddum
}

Vol. 11 No. 1 (2019) pp 95-111

DOI: http://dx.doi.org/10.21580/at.v11i1.3802

\section{PEMANFAATAN SOFTWARE GEOGEBRA UNTUK MENUNJANG PENCAPAIAN STANDAR KOMPETENSI GURU MATEMATIKA MTS DI KOTA SEMARANG}

\author{
Budi Cahyono ${ }^{1}$, Eva Khoirun Nisa ${ }^{2}$ \\ ${ }^{1,2}$ Universitas Islam Negeri Walisongo Semarang \\ Email: ${ }^{1}$ budi.cahyono@gmail.com, ${ }^{2}$ evakn@walisongo.ac.id
}

\begin{abstract}
Information and communication technology (ICT) cannot be separated from education. For professional competence, junior high school/ MTs mathematics teachers must be able to use ICT to communicate and develop themselves. At present, there are many uses of mathematical application programs in mathematics learning, one of which is Geogebra software. Geogebra can be used as a demonstration and visualization media, construction aids and the process of discovering mathematical concepts. To belp MTs math teachers in the Semarang in teaching geometry that is indeed felt abstract and difficult for most students, Geogebra software training is given. With the training, MTs mathematics teachers in Semarang were able to utilize Geogebra's software in achieving competency standards by making a project correctly in the form of visualizing a learning material that could be implemented in the classroom.
\end{abstract}

Keywords: Geogebra, competency standard, mathematics

\begin{abstract}
Abstrak
Teknologi informasi dan komunikasi (TIK) tidak dapat lepas dari dunia pendidikan. Untuk kompetensi profesional, guru mata pelajaran matematika SMP/MTs harus mampu memanfaatkan TIK untuk berkomunikasi dan mengembangkan diri. Saat ini, telah banyak penggunaan program aplikasi matematika dalam pembelajaran matematika salah satunya adalah software Geogebra. Geogebra dapat dijadikan sebagai media demonstrasi dan visualisasi, alat bantu konstruksi dan proses penemuan konsep matematika. Untuk membantu guru-guru matematika MTs di Kota Semarang dalam mengajarkan materi geometri yang memang dirasakan abstrak dan sulit bagi sebagian besar siswa maka diberikan pelatihan software Geogebra. Dengan adanya pelatihan tersebut, Budi C. \& Eva K., Pemanfaatan Software...


guru-guru matematika MTs di Kota Semarang mampu memanfaatkan software Geogebra dalam pencapaian standar kompetensi dengan membuat sebuah proyek dengan benar berupa visualisasi suatu materi pembelajaran yang dapat diimplementasikan di kelas.

Keywords: Geogebra, standar kompetensi, matematika

\section{Pendahuluan}

Dalam Permendiknas Nomor 16 Tahun 2007 telah ditegaskan bahwa salah satu kompetensi pedagogik yang harus dimiliki guru mata pelajaran matematika SMP/MTs adalah mampu memanfaatkan teknologi informasi dan komunikasi untuk kepentingan pembelajaran. Sementara untuk kompetensi profesional, guru mata pelajaran matematika SMP/MTs harus mampu memanfaatkan teknologi informasi dan komunikasi (TIK) untuk berkomunikasi dan mengembangkan diri. Ini menunjukkan bahwa kemampuan memanfaatkan TIK bukanlah hanya menjadi monopoli bagi guru bidang TIK saja, tetapi guru mata pelajaran matematika SMP/MTs juga wajib untuk mampu memanfaatkan TIK.

Kemajuan TIK yang begitu pesat telah membawa dampak besar dalam pembelajaran matematika. Pengaplikasian utama dari teknologi dalam pembelajaran matematika adalah adanya pengintegrasian perangkat lunak dalam pembelajaran matematika. Saat ini, penggunaan program aplikasi matematika telah memberi warna tersendiri dalam pembelajaran matematika karena telah banyak perangkat lunak yang telah dikembangkan dan dimanfaatkan dalam pembelajaran matematika. 
Menurut Preiner':

Computer algebra systems, dynamic geometry software, and spreadsheets are the main types of educational software currently used for mathematics teaching and learning. Each of the programs has its own advantages and is especially useful for treating a certain selection of mathematical topics or supports certain instructional approaches".

Perangkat lunak Geogebra merupakan salah satu produk kemajuan teknologi yang saat ini banyak dimanfaatkan dalam pembelajaran matematika. Dengan berbagai keunggulan yang dimilikinya, saat ini Geogebra banyak dimanfaatkan sebagai alat bantu untuk mengkonstruksi, mendemonstrasikan atau memvisualisasikan konsep-konsep abstrak yang ada pada matematika khususnya pada bidang geometri ${ }^{23}$. Kilpatrick et $\mathrm{al}^{4}$ mengungkapkan dalam hasil penelitiannya bahwa Siswa berpendapat GeoGebra sangat membantu dalam menyelesaikan masalah matematika dan dalam beberapa hal untuk menyelesaikan masalah matematika menggunaan komputer lebih cocok dibanding menggunakan kertas dan pensil. sehingga Geogebra memungkinkan mahasiswa untuk aktif dalam membangun pemahaman geometri sesuai pendapat Markus Hohenwarter ${ }^{5}$ dan Aksoy $^{6}$ bahwa Geogebra merupakan Software yang

${ }^{1}$ Preiner, J. "Introducing Dynamic Mathematics Software to Mathematics Teachers: the Case of GeoGebra." PhD diss., University of Salzburg, 2008.

2 Antohe, V, "Limits of Educational Soft GeoGebra in a Criticall Constructive Review," Annals. Computer Science Series 7th Tome 1st (2009): . 47- 54

3 Iranzo, N. "Influence of Dynamic Geometry Software on Plane Geometry Problem Solving Strategies." PhD diss., Universitat Autònoma de Barcelona 2009.

${ }^{4}$ Kilpatrick, J. et al., Adding it up: Helping Children Learn Mathematics (Washington, DC : National Academy Press, 2001)

5 Markus Hohenwarter, and Judith Hohenwarter, " Teaching And Calculus With Free Dinamic Mathematics Softwre Geogebra," http://tsg.icme11.org/document/get/666, 2008. 
dikembangkan pada program komputer yang bersifat dinamis dan interaktif untuk mendukung pembelajaran dan penyelesaian persoalan matematika khususnya geometri, aljabar, dan kalkulus. Sebagai sistem geometri dinamik, konstruksi pada Geogebra dapat dilakukan dengan titik, vektor, ruas garis, garis, irisan kerucut, fungsi. Perangkat lunak Geogebra sangat mudah diperoleh karena dapat diunduh secara gratis. Di samping itu, perangkat lunak Geogebra juga sangat mudah dioperasikan karena menggunakan sintaks atau perintah yang sangat sederhana. Sesuai pendapat Hohenwarter \& Fuchs ${ }^{7}$, GeoGebra sangat bermanfaat sebagai media pembelajaran matematika dengan beragam aktivitas sebagai berikut.

1. Sebagai media demonstrasi dan visualisasi

Dalam hal ini, dalam pembelajaran yang bersifat tradisional, guru memanfaatkan GeoGebra untuk mendemonstrasikan dan memvisualisasikan konsep-konsep matematika tertentu.

2. Sebagai alat bantu konstruksi

Dalam hal ini GeoGebra digunakan untuk memvisualisasikan konstruksi konsep matematika tertentu, misalnya mengkonstruksi lingkaran dalam maupun lingkaran luar segitiga, atau garis singgung.

3. Sebagai alat bantu proses penemuan

${ }^{6}$ Aksoy, Y., Bayazit, İ. \& Soybaş, D, "The Effects of GeoGebra in Conjectures and Proofs", First North American GeoGebra Conference, (2010): 190-195

7 Markus Hohenwarter and Fuchs, K, "Combination of Dynamic Geometry, Algebra, and Calculus in the Software System Geogebra," www.geogebra.org/publications/pecs_2004.pdf, 2004 
Dalam hal ini GeoGebra digunakan sebagai alat bantu bagi siswa untuk menemukan suatu konsep matematis, misalnya tempat kedudukan titik-titik atau karakteristik grafik parabola.

Melihat kemudahan dalam memperoleh maupun dalam pengoperasiannya, sudah selayaknya guru-guru matematika SMP/MTs mempertimbangkan untuk menggunakan perangkat lunak Geogebra dalam mengajarkan materi-materi geometri yang memang dirasakan abstrak dan sulit bagi sebagian besar siswa di tingkat SMP/MTs.

Berdasarkan hasil observasi dan wawancara pengusul dengan guru mata pelajaran matematika pada saat menjadi Dosen Pendamping Lapangan (DPL) PPL di MTs N 1 Semarang, MTs N 2 Semarang didapat kesimpulan mayoritas peserta guru mata pelajaran matematika tingkat MTs, belum banyak yang mampu menguasai Geogebra dan bahkan masih banyak yang baru tahu perangkat lunak Geogebra itu, belum tahu bahwa perangkat lunak Geogebra itu adalah perangkat lunak yang gratis. Kondisi tersebut juga disampaikan oleh ketua MGMP matematika MTs Kota Semarang bahwa guru matematika di kota semarang belum menggunakan perkembangan iptek dengan baik, khususnya yang berhubungan dengan program-program komputer seperti Geogebra dan adanya permohonan oleh pengurus MGMP MTs Mata Pelajaran Matematika Kota Semarang kepada pengusul untuk bersedia memberikan pelatihan menggunakan perangkat lunak Geogebra untuk mengoptimalkan proses pembelajaran.

Selain itu berdasarkan hasil observasi dan wawancara tersebut dapat diambil kesimpulan bahwa guru mata pelajaran matematika tingkat MTs di kota Semarang sama sekali belum pernah menggunakan 
perangkat lunak Geogebra dalam pembelajaran matematika, belum pernah mendapat kesempatan untuk menggunakan perangkat lunak Geogebra secara intensif melalui workshop maupun pelatihan, dan melihat kemudahan dalam memperoleh maupun dalam pengoperasiannya merasa tertarik dan sangat perlu untuk memperoleh pelatihan menggunakan perangkat lunak Geogebra.

Berdasarkan analisis situasi yang telah diuraikan di depan dapat disimpulkan bahwa guru mata pelajaran matematika tingkat SMP/MTs di Kota Semarang belum banyak yang mampu menguasai Geogebra. Permasalahan tersebut muncul disebabkan karena minimnya pengetahuan guru tentang perangkat lunak Geogebra. Oleh karena itu, permasalahan yang akan ditangani melalui kegiatan pengabdian masyarakat ini adalah : Rendahnya pengetahuan guru matematika tingkat SMP/MTs di Kota Semarang dalam memanfaatkan Geogebra pada pembelajaran matematika, Rendahnya kemampuan guru matematika tingkat SMP/MTs di Kota Semarang dalam memanfaatkan Geogebra pada pembelajaran matematika dan Tingginya minat guru MTs/SMP di Kota Semarang untuk mempelajari program-program software untuk membantu proses pembelajaran, salah satunya adalah Geogebra. Dari kondisi yang dipaparkan di atas maka tujuan kegiatan pengabdian masyarakat ini secara operasional diuraikan seperti berikut.

a) Meningkatkan pengetahuan dan kemampuan guru matematika tingkat SMP/MTs Kota Semarang dalam memanfaatkan Geogebra pada pembelajaran matematika.

b) Memberi kesempatan kepada guru matematika tingkat SMP/MTs di Kota Semarang untuk mengikuti kegiatan pendidikan dan pelatihan 
guna meningkatkan kompetensi pedagogik maupun kompetensi profesionalnya.

\section{Metodologi}

Tujuan yang diangkat dalam kegiatan pengabdian pada masyarakat ini adalah meningkatkan pengetahuan dan kemampuan guru matematika tingkat SMP/MTs di Kota Semarang dalam memanfaatkan Geogebra pada pembelajaran matematika. Oleh karena itu, diusulkan kerangka pemecahan masalah secara operasional sebagai berikut: menetapkan jumlah peserta pelatihan dengan mengundang semua guru matematika tingkat SMP/MTs yang ada di Kota Semarang, memberikan materi pelatihan berupa pengetahuan memanfaatkan Geogebra pada pembelajaran matematika, dan memberi kesempatan kepada guru untuk berlatih merancang pembelajaran matematika dengan memanfaatkan Geogebra.

Kegiatan ini menggunakan metode berbentuk pelatihan keterampilan melalui ekspositori dan demonstrasi (praktek) di kelas melalui tahapan seperti berikut.

a) Pada awal kegiatan, para peserta akan diberikan teori-teori pendukung yang berkaitan dengan aspek-aspek yang akan dilatihkan.

b) Peserta berlatih atau melakukan praktek secara mandiri atau berkelompok untuk berlatih merancang pembelajaran matematika dengan memanfaatkan Geogebra di bawah bimbingan nara sumber atau instruktur yang ditunjuk.

Untuk melaksanakan kegiatan tersebut digunakan beberapa metode pelatihan, yaitu:

1. Metode Ekspositori 
Metode ekspositori dipilih untuk memberikan penjelasan tentang memanfaatkan Geogebra pada pembelajaran matematika.

2. Metode Tanya Jawab

Metode tanya jawab sangat penting bagi para peserta pelatihan, baik di saat menerima penjelasan tentang memanfaatkan Geogebra pada pembelajaran matematika serta saat mempraktekkannya, Metode ini memungkinkan guru menggali pengetahuan sebanyak-banyaknya tentang memanfaatkan Geogebra pada pembelajaran matematika dan juga pengalaman setelah praktek memanfaatkan Geogebra pada pembelajaran matematika

3. Metode Simulasi

Metode simulasi ini sangat penting diberikan kepada para peserta pelatihan untuk memberikan kesempatan mempraktekan materi pelatihan yang diperoleh. Harapannya, peserta pelatihan akan benar-benar menguasai materi pelatihan yang diterima, mengetahui tingkat kemampuannya dalam memanfaatkan Geogebra pada pembelajaran matematika secara teknis dan kemudian mengidentifikasi kesulitan-kesulitan (jika masih ada) untuk kemudian dipecahkan.

Untuk melihat keberhasilan pelaksanaan kegiatan perlu diadakan evaluasi- Evaluasi yang dilaksanakan dalam kegiatan ini adalah sebagai berikut.

a) Evaluasi program, dilakukan sebelum dan setelah kegiatan dilaksanakan. Evaluasi ini bertujuan untuk mengetahui apakah 
program kegiatan sudah sesuai dengan tujuan yang akan dilaksanakan.

b) Evaluasi proses, dilakukan pada saat kegiatan dilaksanakan. Aspek yang dievaluasi adalah kehadiran dan aktivitas peserta dalam mengikuti pelatihan. Keberhasilan dapat dilihat dari kehadiran peserta yang mencapai lebih dari $85 \%$ dan aktivitasnya selama kegiatan tinggi.

c) Evaluasi hasil, dilaksanakan pada akhir kegiatan. Aspek yang dievaluasi adalah pengetahuan dan kemampuan peserta dalam memanfaatkan Geogebra pada pembelajaran matematika.

Secara spesifik aspek, teknik, instrumen serta kriteria evaluasi yang dilakukan dapat disajikan dalam tabel berikut.

Tabel 1. Evaluasi Pelaksanaan Kegiatan

\begin{tabular}{lllll}
\hline No & Aspek & Teknik & Instrumen & Kriteria \\
& Evaluasi & &
\end{tabular}

\begin{tabular}{|c|c|c|c|c|}
\hline 1 & Program & Kuisioner & $\begin{array}{l}\text { Angket/ } \\
\text { Kuisioner }\end{array}$ & $\begin{array}{l}\text { Kesesuaian dengan } \\
\text { tujuan }\end{array}$ \\
\hline 2 & $\begin{array}{l}\text { Proses } \\
\text { Pelaksanaan }\end{array}$ & observasi & 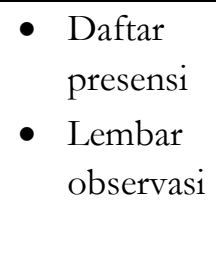 & $\begin{array}{l}\text { - } \begin{array}{l}\text { Kehadiran lebih } \\
\text { dari } 85 \%\end{array} \\
\text { - Aktivitas peserta } \\
\text { dalam kegiatan } \\
\text { tinggi }\end{array}$ \\
\hline 3 & $\begin{array}{l}\text { Hasil } \\
\text { Pelaksanaan } \\
\text { (pengetahuan } \\
\text { dan } \\
\text { kemampuan } \\
\text { peserta) }\end{array}$ & $\begin{array}{l}\text { Penugasan } \\
\text { membuat } \\
\text { suatu } \\
\text { proyek }\end{array}$ & $\begin{array}{l}\text { Hasil proyek } \\
\text { yang } \\
\text { dibuat }\end{array}$ & $\begin{array}{l}\text { Peserta mampu } \\
\text { menyelesaikan } \\
\text { tugas/proyek yang } \\
\text { diberikan dengan } \\
\text { baik/benar }\end{array}$ \\
\hline
\end{tabular}




\section{Hasil dan Pembahasan}

Pada awal kegiatan, melalui ekspositori narasumber menyajikan materi pelatihan berupa pengetahuan memanfaatkan Geogebra pada pembelajaran matematika dengan bantuan modul petunjuk praktikum "Pelatihan Geogebra dalam Pembelajaran Matematika" dan dibantu oleh dua orang pembantu narasumber untuk mempermudah memberikan pengarahan kepada peserta jika ada kesulitan. Dalam modul petunjuk praktikum tersebut disajikan berbagai contoh tentang pemanfaatan Geogebra dalam pembelajaran matematika dan setiap peserta mendapatkan modul petunjuk praktikum tersebut sehingga mempermudah peserta dalam menggunakan software Geogebra.

Kemudian kegiatan dilanjutkan dengan memberikan kesempatan kepada peserta untuk berlatih atau melakukan praktek secara individu membuat proyek mengembangkan perangkat pembelajaran yang dapat diimplementasikan di kelas dengan memanfaatkan software Geogebra dengan pendampingan narasumber dan dua orang pembantu praktikum. Berikut beberapa hasil karya peserta disajikan pada gambar berikut.;

Hasil dalam upaya membuat animasi pembelajaran jaring-jaring Prisma, pada gambar 1: 


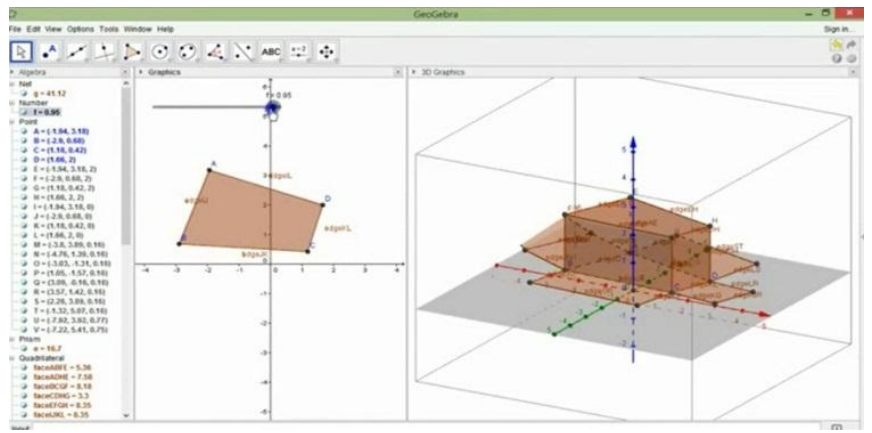

Gambar 1

Animasi Pembelajaran Jaring-jaring Prisma

Hasil dalam upaya membuat animasi pembelajaran jarak titik dan garis pada gambar 2:

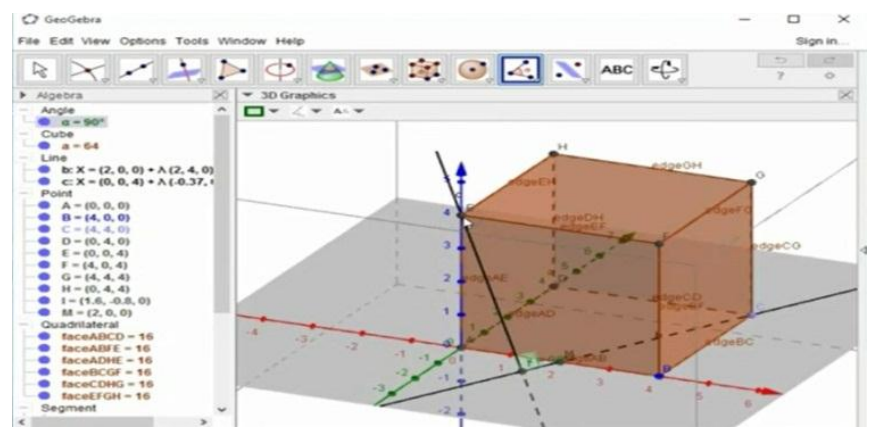

Gambar 2

Animasi Pembelajaran Jarak Titik dan Garis

Hasil dalam upaya membuat animasi pembelajaran persamaan linier pada gambar 3: 


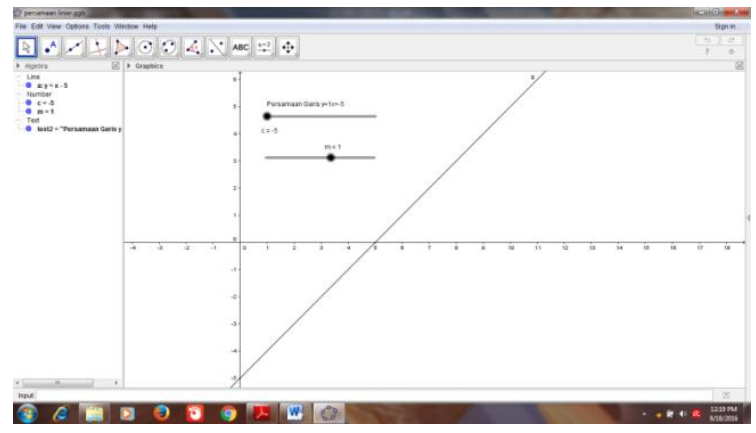

Gambar 3

Animasi Pembelajaran Persamaan Linier

Hasil dalam upaya membuat animasi pembelajaran Volume benda putar pada gambar 4 :

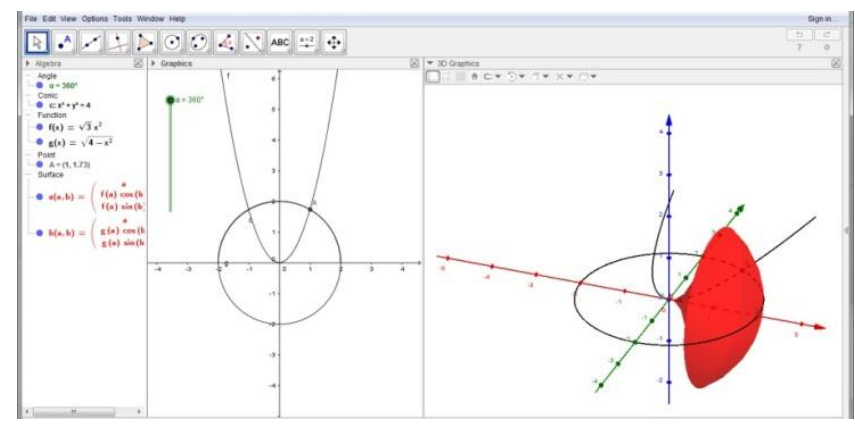

Gambar 4

Animasi Pembelajaran Volume Benda Putar

Untuk menilai keberhasilan program yang dilaksanakan maka dilakukan evaluasi. Berdasarkan hasil evaluasi terhadap pelaksanaan kegiatan pelatihan yang dilaksanakan diperoleh hasil sebagai berikut.

1. Berdasarkan respon peserta pelatihan yang tertuang dalam isian angket, diketahui bahwa seluruh peserta menyatakan bahwa kegiatan yang dilaksanakan sesuai dengan tujuan yang ingin disasar 
yakni meningkatkan pengetahuan dan kemampuan guru matematika tingkat SMP/MTs di kecamatan Abang dalam memanfaatkan Geogebra pada pembelajaran matematika.

2. Seluruh peserta terlihat sangat antusias dalam mengikuti program pelatihan. Hal ini bisa dilihat dari kehadiran seluruh peserta mulai dari awal kegiatan sampai akhir kegiatan.

3. Seluruh peserta mampu membuat sebuah proyek dengan benar berupa visualisasi suatu materi pembelajaran berbasis software Geogebra yang dapat diimplementasikan di kelas.

4. Peserta sangat tertarik dan sangat ingin menerapkan program geogebra dalam proses pembelajaran di kelas dalam upaya meningkatkan tingkat pemahaman siswa dalam belajar geometri khususnya bangun ruang.

Dari 18 peserta yang berasal dari 11 sekolah MTs N 1, MTs N 2, MTs Darul Ulum, MTs Nurussibyan, MTs Al Wathoniyah, MTs Darus Sa'adah, MTs Darus Sa'adah, MTs FutuhiyYah Palebon, MTs Infarul Ghoy, MTs Syaroful Millah, MTs Tawang Rejosari, MTs Al Khoiriyah dan MTs Fatahillah yang ada di kota semarang pada pada umumnya mengalami kesulitan dalam menggunakan/memahami sintaks atau perintah dalam Geogebra saat peserta berlatih atau melakukan praktek secara individu membuat proyek mengembangkan perangkat pembelajaran berbasis software Geogebra. Hal ini dapat dimaklumi karena seluruh peserta belum terbiasa menggunakan software Geogebra. Untuk mengatasi masalah ini peserta diarahkan untuk melihat modul petunjuk praktikum penggunaan Geogebra dalam pembelajaran matematika yang sudah diberikan. Dengan arahan dari narasumber dan dua orang 
pendamping praktikum maka secara perlahan seluruh peserta sudah mulai bisa membuat sintaks pada Geogebra dengan baik. Berikut dokumentasi keseriusan dan penampakan kebingungan peserta pada saat belajar Geogebra.

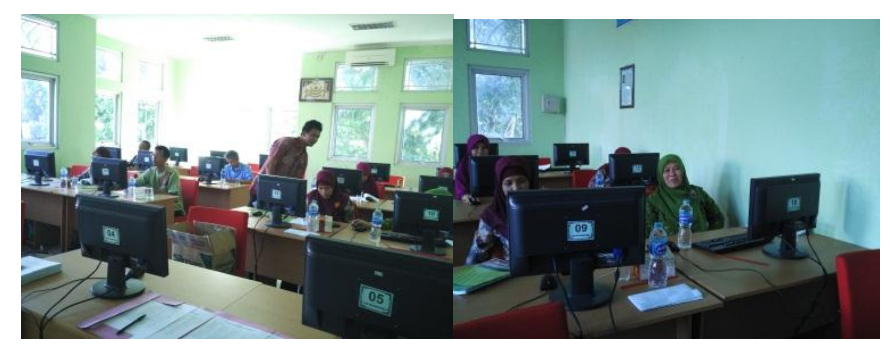

\section{Gambar 5}

\section{Suasana Pelatihan Pemanfaatan Geogebra}

Dengan adanya modul petunjuk praktikum pemanfaatan Geogebra dalam pembelajaran matematika yang diberikan dan dengan diberikannya pendampingan secara intensif maka seluruh peserta telah mampu membuat sebuah proyek sederhana yang bisa diimplementasikan di kelas pada saat pelaksanaan pembelajaran matematika.

Program software Geogebra yang free dan mudah diakses akan memberikan kesempatan kepada guru untuk terus berupaya berlatih dalam merancang pembelajaran matematika dengan berbasis Geogebra dan menyebarluaskannya kepada guru lain yang belum mendapatkan program pelatihan secara khusus, sehingga kemampuan guru tersebut dalam menguasai program Geogebra semakin terasah dan meningkat. Dari seluruh guru yakin bahwa dengan program Geogebra akan mampu meningkatkan prestasi belajar mahasiswa khususnya pada materi aljabar 
dan geometri hal tersebut sesuai dengan hasil penelitian Cahyono ${ }^{8}$ yang menyatakan keaktifan dan hasil prestasi belajar mahasiswa pada mata geometri transformasi program studi Pendidikan Matematika UIN Walisongo Semarang meningkat setelah menggunakan media Geogebra dan screencase dan pengaruhnya sangat kuat karena dari hasil analisis regresi linier didapat kesimpulan bahwa 81,3\% hasil belajar mahasiswa dipengaruhi oleh keaktifan mahasiswa setelah menggunakan media geogebra, 19,7\% dipengaruhi oleh variabel lainnya. Berikut sampul modul geogebra yang digunakan.

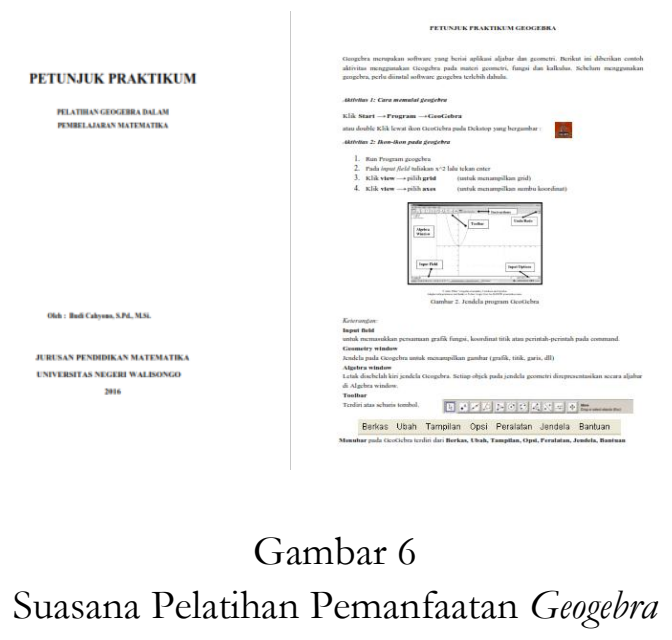

\section{Kesimpulan dan Saran}

Berdasarkan hasil evaluasi terhadap pelaksanaan kegiatan pelatihan yang dilaksanakan maka dapat disimpulkan sebagai berikut.

8 Budi Cahyono, Implementasi Media Software Geogebra dan Screencase dalam Pembelajaran Geometri Trasformasi untuk Meningkatkan Hasil Belajar Mahasiswa Tadris Matematika, (Semarang: LP2M IAIN Walisongo Semarang, 2014) 
a. Berdasarkan respon peserta pelatihan yang tertuang dalam isian angket, diketahui bahwa seluruh peserta menyatakan bahwa kegiatan yang dilaksanakan sesuai dengan tujuan yang ingin disasar yakni meningkatkan pengetahuan dan kemampuan guru matematika tingkat MTs di kota Semarang dalam memanfaatkan Geogebra pada pembelajaran matematika.

b. Seluruh peserta terlihat sangat antusias dalam mengikuti program pelatihan. Hal ini bisa dilihat dari kehadiran seluruh peserta mulai dari awal kegiatan sampai akhir kegiatan.

c. Seluruh peserta mampu membuat sebuah proyek dengan benar berupa visualisasi suatu materi pembelajaran berbasis software Geogebra yang dapat diimplementasikan di kelas sehingga kopetensi guru khususnya dalam menggunakan computer sebagai media pembelajaran telah meningkat.

Berdasarkan respon yang diberikan oleh peserta pelatihan dan berdasarkan wawancara dengan beberapa orang peserta pelatihan tampaknya perlu ada kegiatan sejenis dengan menyasar materi matematika yang lebih luas dengan waktu pelaksanaan yang lebih lama karena peserta merasakan manfaat yang besar terkait dengan pemanfaatan Geogebra pada pembelajaran matematika.

\section{Referensi}

Antohe, V., Limits of Educational Soft GeoGebra in a Criticall Constructive Review, Annals. Computer Science Series. 7th Tome 1st Fasc (2009):47- 54

Aksoy, Y., Bayazit, İ. \& Soybaş, D., The Effects of GeoGebra in Conjectures and Proofs, First North American GeoGebra Conferenc, (2010): 190-195 
Arranz, M. J., Losada, R., Mora, A. J., and Sada, M., Realities from GeoGebra, MSOR Connections Vol 9 No 2 (May - July 2009): $17-23$.

Cahyono, Budi, Implementasi Media Software Geogebra dan Screencase dalam Pembelajaran Geometri Trasformasi untuk Meningkatkan Hasil Belajar Mahasiswa Tadris Matematika. Semarang; LPM IAIN Walisongo Semarang, 2014.

Hohenwarter, Markus and Judith Hohenwarter. "Teaching and calculus with free dinamic mathematics softwre GeoGebra." .http://tsg.icme11.org/document/get/666. 2008. (accessed January 23, 2013)

Hohenwarter, M. \& Fuchs, K. "Combination of Dynamic Geometry, Algebra, and Calculus in the Software System Geogebra." www.geogebra.org/publications/pecs_2004.pdf.(accessed

November 16, 2010)

Iranzo, N. "Influence of Dynamic Geometry Software on Plane Geometry Problem Solving Strategies." Doctoral Thesis, Universitat Autònoma de Barcelona, 2009.

Kilpatrick, J. et al. Adding it up: Helping Children Learn Mathematics. Washington, DC : National Academy Press. 2001

Preiner, J. "Introducing Dynamic Mathematics Software to Mathematics Teachers: the Case of GeoGebra". PhD diss., University of Salzburg, 2008. 